\title{
Parques da Copa do Ceará: uma proposta de gestão de roteiros de ecoturismo para o desenvolvimento regional
}

\author{
Parks's Cup Ceará: a proposal for management of ecotourism routes for \\ regional development
}

Hermógenes Henrique Oliveira Nascimento

\begin{abstract}
RESUMO
O presente trabalho é uma proposta de gestão de roteiros integrados de ecoturismo que visa o desenvolvimento socioambiental do Estado do Ceará. Nesse sentido, o objetivo central é estruturar um rol de serviços integrados que viabilize a implantação e consolidação de roteiros em 06 (seis) Unidades de Conservação estaduais para serem os Parques da Copa. Para tanto, adotou-se uma metodologia de governança participativa tanto na fase analítica quanto na propositiva, com as oficinas técnicas e de capacitação. Observa-se, parcialmente, pelos cenários já obtidos que há aceitação e comprometimento de órgãos públicos, empresa privadas e comunidades do entorno para que se avance nos trabalhos e que tornem as Unidades de Conservação um verdadeiro equipamento de uso público e de preservação.
\end{abstract}

PALAVRAS-CHAVE: Gestão; Roteirização; Unidades de Conservação; Ecoturismo; Parques da Copa.

\section{ABSTRACT}

This work is a proposal for integrated management of ecotourism itineraries aimed at environmental development of the State of Ceará. In this sense, the main objective is to structure a roster of integrated services which facilitates the deployment and consolidation of itineraries in six (06) state Protect Areas for Parks's Cup. Therefore, we adopted a methodology of participatory governance both in the analytical and in purposeful, with technical workshops and training. There are, in part, by the scenarios already obtained there acceptance and commitment of public agencies, private companies and the surrounding communities so that they move forward in the work and to make the protected areas a real machine for public use and preservation.

KEYWORDS: : Management; Routing; Protects Areas; Ecotourism; Parks's Cup. 


\section{Introdução}

Verifica-se que a partir da década de 1970, as preocupações com o desenvolvimento econômico, a degradação do meio ambiente e as questões sociais alcançaram a atividade turística, tanto na esfera acadêmica, quanto na das organizações civis, evidenciando a necessidade de conservação do meio ambiente por meio de técnicas sustentáveis (MTur, 2007).

Por esse motivo, o ecoturismo vem se confirmando como um produto turístico de real potencial econômico-social, capaz de propiciar a divulgação do patrimônio ambiental e cultural, tanto no mercado interno como externo, uma vez que o Brasil possui uma riqueza natural de inestimável valor.

Esse segmento do turismo configura-se, também, como uma importante alternativa de desenvolvimento, se operado em bases sustentáveis, pois quando utiliza racionalmente os recursos naturais e culturais, sem comprometer a sua capacidade de renovação e conservação, pode gerar novos modelos de desenvolvimento para a sociedade.

Dessa forma, para fins de entendimento, conceitua-se, o ecoturismo como:

um segmento da atividade turística que utiliza, de forma sustentável, o patrimônio natural e cultural, incentiva sua conservação e busca a formação de uma consciência ambientalista através da interpretação do ambiente, promovendo o bem-estar das populações envolvidas (EMBRATUR, 1994).

Nesse caminho, o Conselho de Políticas e Gestão do Meio Ambiente (CONPAM), com esta proposta, pretende dar um salto significativo na implantação e, posteriormente, na consolidação das atividades turísticas em unidades de conservação (UCs) no Ceará. Assim, além de planejar, estruturar, organizar e monitorar a visitação pública nas UC, a proposta supracitada visa também associar o turismo à valorização e proteção do patrimônio natural das áreas envolvidas. O caráter único e a fragilidade dos ecossistemas exigem precaução no planejamento e execução das atividades. Os resultados dos Projetos devem subsidiar políticas públicas que visem o ordenamento e estruturação da visitação pública para a sua efetivação no Sistema Nacional de Unidades de Conservação.

A proposta objetiva, prioritariamente, consolidar a vocação do turismo sustentável na área de influência para a conservação da natureza e, também, ampliar sua participação no desenvolvimento regional e fomentar os arranjos produtivos locais (APL) do turismo de natureza. Logo, a partir do enfoque central de implementar 06 (seis) roteiros de ecoturismo com objetivos que serão alcançados por meio da integração dos atrativos turísticos das UC; apoio à cadeia produtiva do ecoturismo regional e pelo fortalecimento da capacidade de gestão pública e social.

As diretrizes para a implantação de uma gestão integrada do ecoturismo, portanto, baseia-se, em certos princípios calçados no: uso sustentável dos recursos naturais; manutenção da diversidade biológica e cultural; desenvolvimento de políticas públicas para o turismo; suporte às economias locais; envolvimento das comunidades da 
região; consulta ao público e aos atores envolvidos com intuito de incentivar o planejamento participativo; capacitação de mão de obra; marketing turístico responsável; fomento do consumo consciente; valorização da produção de artefatos locais; e o desenvolvimento de pesquisa.

\section{Contextualizando a problemática}

A Copa do Mundo FIFA de 2014 será a 20ª edição do evento e terá como país anfitrião o Brasil. A competição ocorrerá pela quinta vez na zona sul-americana após 36 anos. No dia 30 de outubro de 2007 a FIFA ratificou o Brasil como país-sede e a escolha das cidades-sede aconteceu em 31 de maio de 2009. Dentre as 12 cidades escolhidas, uma dessas é Fortaleza que é a capital do Estado do Ceará.

Como aconteceu na copa de 2006 na Alemanha, o Brasil quer garantir sustentabilidade ambiental, social e econômica para a Copa de 2014. A chamada "Copa Verde" propõe adotar medidas ambientalmente sustentáveis que privilegiem a mobilidade urbana, a redução do consumo de água e energia, certificação de estádios para que tenham aproveitamento de água da chuva, aproveitamento da energia solar e da ventilação natural, acessibilidade para pessoas portadoras de qualquer necessidade especial e compras sustentáveis.

Considerando a assinatura do Acordo de Cooperação Técnica entre o Ministério do Meio Ambiente e o Ministério do Esporte, em 29 de abril de 2010, com vistas ao estabelecimento de agenda de trabalho conjunta, voltada em especial ao desenvolvimento das diretrizes de sustentabilidade ambiental da Copa do Mundo FIFA 2014, foram criadas Câmaras Técnicas de meio Ambiente e Sustentabilidade nas cidades sedes e Núcleos Temáticos, para elaboração de uma Agenda de Meio Ambiente e Sustentabilidade.

Além de seu futebol, a natureza exuberante é uma das mais fortes imagens do Brasil no exterior. Quando se pensa em turismo de natureza, as Unidades de Conservação (UCs), principalmente, os Parques ocupam a primeira opção procurada pelos viajantes.

Os Parques da Copa associam estas fortes marcas com o objetivo de oferecer aos turistas, que virão ao Brasil para a Copa do Mundo, a estrutura adequada nas regiões abrangidas pelo projeto.

Um evento desse porte de abrangência intercontinental traz oportunidades de agregação de valor imensurável às atividades turísticas, científicas e da produção associada dos demais setores econômicos instalados no Estado, notadamente por meio do Projeto Parques da Copa, do Ministério do Meio Ambiente. Com foco nos eixos: turismo sustentável, conservação e educação ambiental; importante estabelecer um modelo de desenvolvimento socioeconômico de base territorial sustentável que favoreça a preservação dos patrimônios: material e imaterial, por intermédio inclusive das riquezas regionais. Assim sendo, esforços institucionais devem convergir para garantir o sucesso deste evento internacional, que pode abrir oportunidades para a ampliação 
e inovação dos negócios instalados, agregação de valor à produção e atração de novos investimentos.

De tal modo, por ser um país de dimensões continentais, abrigando uma biodiversidade exuberante, foram constituídos núcleos temáticos específicos, em cada cidade sede, objetivando identificar as unidades de conservação prioritárias nas regiões no entorno das mesmas, representativas dos diferentes biomas brasileiros, e as políticas e medidas necessárias para que estejam em condições de atenderem a demanda turística derivada da Copa, exibindo aproximadamente aos 600 mil turistas estrangeiros e três milhões de viajantes brasileiros a biodiversidade brasileira, seus atrativos turísticos, científicos e paisagísticos.

No Ceará foram selecionadas, baseadas em critérios de atração e indução turística, 06 (seis) Unidades de Conservação Estaduais nas regiões prioritárias de conservação, representativas dos diferentes biomas cearenses, que farão parte do Projeto Parques da Copa. Sendo assim, as contempladas com as suas respectivas localidades são: o Parque Ecológico do Cocó (Fortaleza), Parque Botânico do Ceará (Caucaia), Parque Estadual Marinho da Pedra da Risca do Meio (Fortaleza), Monumento Natural das Falésias de Beberibe (Beberibe), Monumento Natural dos Monólitos de Quixadá (Quixadá) e Parque Estadual do Sítio Fundão (Crato).

Logo, tais Unidades acima receberão aporte técnico e logístico para se configurar como Roteiros de Ecoturismo objetivando receber com qualidade os visitantes e turistas que vierem ao Ceará na Copa do Mundo de 2014.

\section{Objetivos \\ Objetivo Geral}

Dotar o Estado do Ceará de instrumentos que possibilitem a orientação, diálogo e negociação para implantação e consolidação de 06 (seis) roteiros de ecoturismo nas Unidades de Conservação, do ponto de vista institucional, econômico, cultural, social, ambiental e mercadológico, segundo o grau de desenvolvimento da atividade turística de cada região.

\section{Objetivos Específicos}

- Realizar levantamentos documentais e complementares de campo, com vistas a atualizar e ordenar o conjunto de informações necessárias para um inventário municipal das sedes das Unidades de Conservação nos aspectos geográficos, demográficos, econômicos, políticos, hidrográficos, educacionais, históricos, da fauna, da flora, do relevo, do clima, da infraestrutura e para a qualificação dos roteiros;

- Elaborar os Planos Estratégicos de Desenvolvimento e de Ação do Ecoturismo nas 06 (seis) Unidades de Conservação e entorno que servirão como elementos norteadores para tomadas de decisão, com vistas a implementação dos Roteiros; 
- Produzir um inventário turístico dispondo de informações de Atrativos Turísticos, Equipamentos e Serviços Turísticos e Infraestrutura de Apoio Turístico nas regiões do Projeto;

- Confeccionar documentos-síntese visando a elaboração da Política Estratégica de Desenvolvimento do Ecoturismo para as Unidades de Conservação Estaduais do Ceará.

\section{Escopo do trabalho}

A implementação dos Roteiros de Ecoturismo em Unidades de Conservação no Ceará, objeto deste trabalho, compreende a elaboração dos Planos Estratégicos de Desenvolvimento e de Ação do Ecoturismo de cada uma das 06 (seis) Unidades Estaduais contempladas para o Projeto Parques da Copa; incluindo o diagnóstico e estruturação dos roteiros de ecoturismo que efetivamente serão trabalhados, resultando na produção dos documentos norteadores para tal implementação, como também a elaboração do documento visando a Política Estratégica de Desenvolvimento do Ecoturismo para as 23 (vinte e três) Unidades de Conservação Estaduais do Ceará.

\section{Planos Estratégicos de Desenvolvimento e de Ação do Ecoturismo}

Os Planos Estratégicos de Desenvolvimento e de Ação do Ecoturismo deverão ser consolidados com metas para 5 anos, com projeções e desafios para 10 e 15 anos, compreendendo:

- Análise situacional e avaliação de cenários com projeções de curto, médio e longo prazo das 06 (seis) Unidades de Conservação selecionadas pelo Projeto Parques da Copa.

- Elaboração do Plano Estratégico e de Ação, com indicação dos Projetos Estruturantes e seus possíveis Termos de Referência para subsidiar a execução do Plano em questão.

\section{Análise Situacional e Avaliação do Cenário Projetado das 06 (seis) Unidades de Conservação}

Compreende o conjunto de informações sobre a situação atual e o cenário das 06 (seis) Unidades de Conservação dos Parques da Copa, a análise e a avaliação das informações, as necessidades e as recomendações. A etapa deverá ser desenvolvida considerando os aspectos abaixo relacionados.

\section{Contexto Físico, Territorial e Socioeconômico}

Posicionamento de cada região no contexto estadual e inter-regional e municípios integrantes; caracterização econômica; caracterização ambiental; caracterização sociocultural (comunidades tradicionais, costumes, folclore, manifestações artísticas e 
Parques da Copa do Ceará: uma proposta de gestão de roteiros de ecoturismo para o desenvolvimento

populares); acessibilidade e mobilidade; abastecimento de água e esgotamento sanitário; limpeza pública; energia elétrica; educação e saúde; comunicação; segurança. Deverão também ser levantados outros aspectos relevantes para o desenvolvimento do turismo e os programas e projetos planejados, em execução ou em conclusão.

\section{Contexto Turístico}

Suporte e Apoio da Oferta e Produtos Turísticos: Atrativos turísticos: naturais, culturais, eventos e outros; Equipamentos e serviços turísticos (meios de hospedagem, alimentação e entretenimento, agências de viagem, equipamento para convenções, áreas para manifestações públicas); facilidades (bancos, locadoras de veículos, serviços telefônicos, correios, farmácias, shopping, mercados, feiras, venda de artesanato, serviços de táxi e outros, pontos de venda nas estradas e outras facilidades); segmentos turísticos-âncora; produtos e roteiros turísticos comercializados (empresas que comercializam e forma de comercialização).

Demanda turística nos Polos Regionais: fluxo turístico, origem, movimentação, gasto médio.

Gestão do Turismo: órgãos de turismo na estrutura administrativa dos municípios, participação nos Fóruns de Turismo e Cultura do Estado do Ceará. Sistema de informação, postos de informações turísticas; recursos humanos para o turismo: nível de capacitação dos recursos humanos para o turismo.

Estratégia de Marketing e Promoção: Formas de promoção, divulgação e comercialização da região, roteiros comercializados, agências e operadores que atuam na região.

\section{Análise, avaliação e projeção do potencial turístico}

Análise das informações obtidas em cada região; avaliação do potencial da região para o aumento da oferta, incremento do fluxo turístico, atração de negócios, captação de investimentos. Definição dos produtos principais e produtos complementares.

Elaboração do programa de necessidades em infraestrutura, equipamentos e serviços turísticos, facilidades, capacitação, divulgação, promoção e comercialização; oportunidade de negócios para micro, pequenas, médias e grandes empresas; incentivos estaduais e municipais aos investimentos turísticos e recomendações gerais.

\section{Elaboração dos Planos Estratégicos de Desenvolvimentos e de Ação do Ecotu- rismo}

\section{Planos Estratégicos de Desenvolvimento e de Ação}

Os Planos Estratégicos e de Ação de cada uma das 06 (seis) regiões dos Parques da Copa compreendem as definições estratégicas constituídas por Objetivos 
Centrais e Estratégicos e as propostas das ações contendo: projetos, medidas e instrumentos prioritários e estruturantes, necessários para o desenvolvimento do ecoturismo de cada Unidade.

Objeto Central: Sintetiza o modelo de desenvolvimento do ecoturismo desejado (cenário desejado) para a região, devendo, obrigatoriamente, explicitar os objetivos da demanda (qual mercado) e da oferta (quais produtos).

Objetos Estratégicos: São os temas-chave da região, aqueles que farão passar do cenário atual ao cenário desejado. Abrangem as áreas mais relevantes e de natureza estratégica que permitirão alcançar o objeto central do plano.

Ações: São agrupamentos de projetos, medidas ou instrumentos que devem ser implementado para alcançar os objetivos, estratégias e, portanto, garantir a realização do Plano. Contemplam os programas estruturantes da política de turismo do Estado, com enfoque nos princípios da sustentabilidade e outros que possam vir a ser identificados.

Projetos: Constituídos de ações especificas, medidas ou instrumentos para atingir os objetivos agrupados por linhas de ação, capazes de dar respostas em curto prazo.

$\mathrm{Na}$ elaboração dos Planos, as definições estratégicas para cada uma das regiões fundamentam o conjunto de intervenções programadas de acordo com os objetivos central e estratégico, definindo as ações especificas e projetos prioritários estruturantes. Essas intervenções deverão ser organizadas de maneira cronológica, com objetivos e metas, responsabilidades, prazos de execução e cronograma das atividades e os respectivos Termos de Referência necessários para os encaminhamentos dos trabalhos, abrangendo:

- Roteiros temáticos e segmentados, de acordo com as âncoras regionais e respaldados pelo documento: Diretrizes para uma Política Nacional de Ecoturismo;

- $\quad$ Gestão (definição da forma de gestão do ecoturismo para cada região; qualificação dos serviços, ações programadas para qualificar os roteiros, capacitação de recursos humanos para o ecoturismo; regulação da atividade de turismo de natureza);

- Investimentos em infraestrutura básica, de apoio/suporte e ecoturísticas na geração de bens e serviços para o incremento da atividade;

- Marketing (definição da imagem, marca, produtos a serem ofertados, ações promocionais e de apoio a comercialização), com comunicação e divulgação simultâneos ao decorrer das ações;

- $\quad$ As ações e projetos, a serem realizadas pelos poderes públicos e/ou iniciativa privada, deverão ser apresentados dentro de critérios de prioridade que incluem a imprescindibilidade, a capacidade de articulação, desdobramento e contribuição com outros projetos e a visibilidade dos resultados a curto, médio e longo prazos. 


\section{Etapa de monitoramento, acompanhamento e avaliação do plano}

A proposta deverá incluir os indicadores de impacto e benefício para o qual deverão ser desenvolvidos processos que permitam o acompanhamento, monitoramento e avaliação dos projetos pelo Órgão Gestor Estadual das Unidades de Conservação do Ceará CONPAM.

Ao final desta etapa deverão ser gerados documentos ou informações ao gestor público do órgão, relativo à Política Estratégica Regional do Ecoturismo para as Unidades de Conservação Estaduais.

\section{Política Estratégica de Desenvolvimento do Ecoturismo}

Este documento deve estabelecer objetivos, normas e princípios para programas governamentais e empreendimentos privados voltados para o ecoturismo. A referência para a política deve conter informações sobre o desenvolvimento estadual do turismo de natureza; definir estratégias de ação e regulamentação; apresentar as Unidades de Conservação existentes; mostrar áreas prioritárias para conservação ambiental e; evidenciar potenciais regiões de interesse para o desenvolvimento do ecoturismo.

\section{Produção de Documento-Síntese}

A produção dos documentos-síntese representa o resultado final do Projeto de Implementação de Roteiros de Ecoturismo das Unidades de Conservação Estaduais do Ceará, compreendendo os documentos de que trata o item 4 (Escopo do Trabalho) deste Termo de Referência:

- $\quad$ Planos Estratégicos de Desenvolvimento e de Ação do Ecoturismo para cada uma das 06 (seis) Unidades de Conservação.

- $\quad$ Roteiro de Ecoturismo para 06 (seis) Unidades de Conservação contempladas para o projeto Parques da Copa.

- Política Estratégica de Desenvolvimento do Ecoturismo para as 23 (vinte e três) Unidades de Conservação Estaduais.

\section{Abrangência}

Os estudos técnicos contemplarão as 23 (vinte e três) Unidades de Conservação localizadas no Estado do Ceará, maximizando 06 (seis) dentre essas, com enfoque de roteirização turística para os Parques da Copa. As áreas poderão ser identificadas pelas Figuras 1 e 2.

\section{Atividades}

Todos os procedimentos necessários para a execução efetiva desta etapa devem na sua abrangência especificar:

- Mobilização e organização dos atores locais como forma de conquista dos direitos e deveres, responsabilizando-se para conservação e preservação das áreas naturais;

- Mobilização e sensibilização das comunidades sobre a importância do uso sustentável dos recursos naturais das UCs; 
- Modelo de gestão empresarial, que comungue o compromisso ambiental dos empreendedores, dos agentes públicos com os princípios e diretrizes do ecoturismo;

- $\quad$ Modelo de parceria entre o poder público municipal, Estado, a fim de que este amplie sua ação às comunidades envolvidas no tocante aos serviços públicos essenciais.

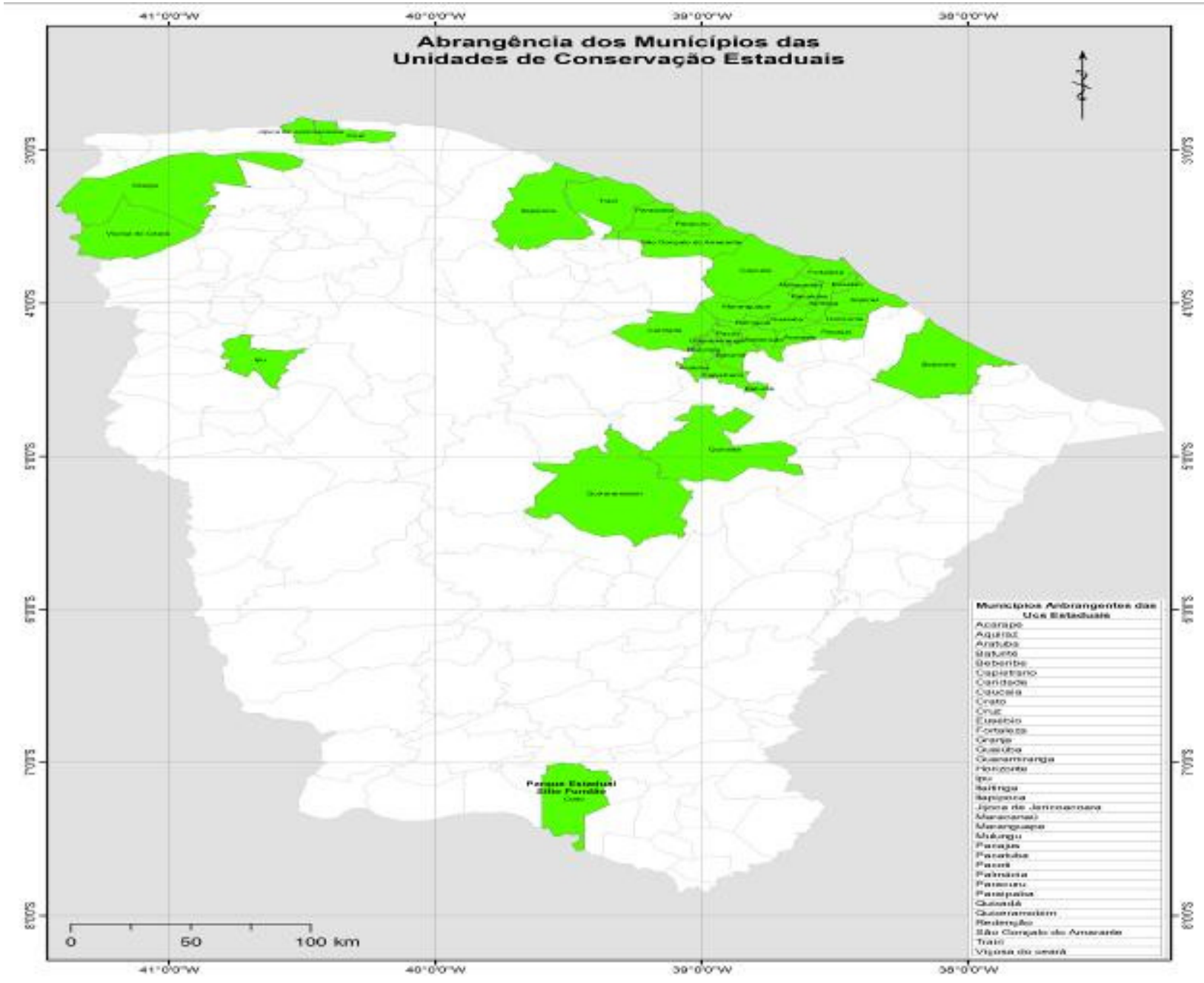

Figura 1: Regiões de influência da proposta de roteirização.

Figure 1: Regions of influence of the proposed routing.

\section{Processo de roteirização}

- Definição de segmentos/tema (pela oferta e demanda);

- Identificação dos atrativos e dos atores envolvidos;

- Avaliação e hierarquização dos atrativos turísticos (categorizar baseados em diretrizes da Embratur e Ministério do Turismo); 
- Levantamento de informações sobre os atrativos (localização, acesso, pontos de referência, agendamentos, etc);

- Identificação dos possíveis impactos socioculturais, ambientais e econômicos;

- Elaboração de roteiro descritivo e operador;

- $\quad$ Precificação e teste do roteiro turístico;

- Promoção e comercialização;

- Monitoria e avaliação.

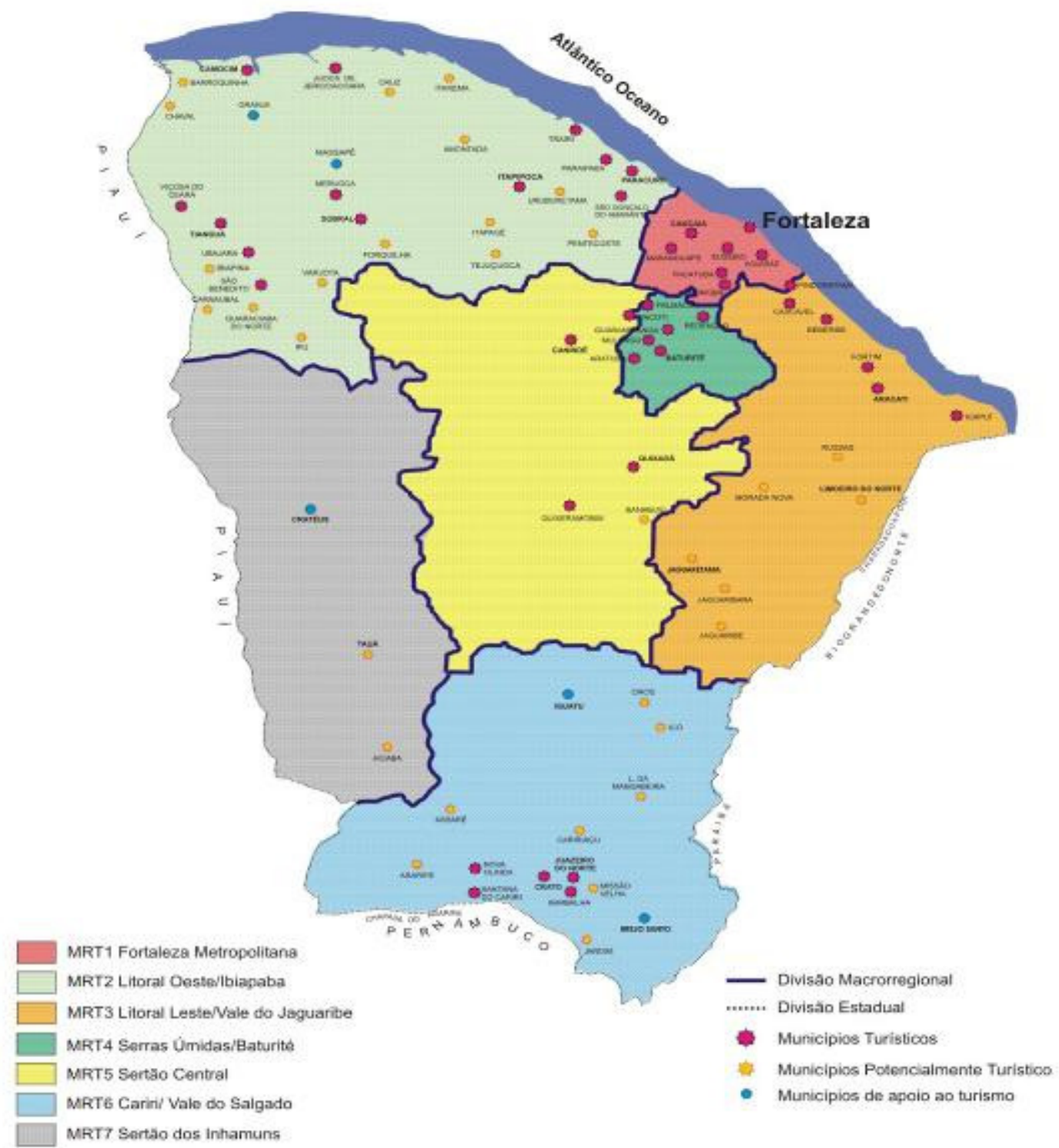

Figura 2: Macrorregiões turísticas do Estado do Ceará.

Figure 2: Macroregions tourist of Ceará State. 


\section{Componentes dos roteiros}

\section{Gestão, proteção e conservação dos recursos naturais}

O processo de roteirização consiste principalmente na adoção de estratégias e ações para minimizar possíveis impactos negativos da visitação turística por meio do uso de um modelo de gestão sustentável da atividade.

Para tanto, é preciso dispor de um conjunto de medidas planejadas, organizadas e gerenciadas de forma sistêmica, capazes de promover a conservação, recuperação, preservação e manejo da área em questão, em sintonia com as demais atividades no território.

\section{Escala do empreendimento e do fluxo de visitantes}

Os Roteiros de Ecoturismo devem ser caracterizados sob dois aspectos principais, em função da capacidade de suporte ${ }^{1}$ de cada ambiente e da atividade desenvolvida:

- Volume e intensidade dos fluxos turísticos - referem-se à quantidade de turistas e à frequência da visitação;

- Porte dos equipamentos turísticos ${ }^{2}$ - diz respeito às dimensões - pequenas, médias e grandes - das instalações que serão utilizadas para o incremento do Ecoturismo.

\section{Paisagem}

A paisagem, além de ser um recurso turístico, é um importante elemento na caracterização dos roteiros, pois são os locais preservados ou conservados e sua atmosfera que compõem o cerne da motivação dos turistas. Nesse sentido, deve-se buscar por infraestrutura, equipamentos e serviços adequados que visam minimizar a intervenção na paisagem local.

As edificações devem observar o meio físico em que estão inseridos (montes, rios, lagos, penhascos, cachoeiras, ilhas e praias), biológicos (flora e fauna) e culturais (ser humano e artefatos em interação), a partir da utilização de elementos que expressem e fortaleçam a identidade local, como artesanatos e comidas típicas. Aspectos da arquitetura devem ser observados, como autenticidade dos elementos arquitetônicos e decorativos, contemplando-se o conforto e a qualidade dos serviços.

Recomenda-se que os equipamentos turísticos que se destacam no segmento do Ecoturismo devam revelar as práticas e técnicas de construção utilizadas nas localidades e regiões, que pode ser conferida na arquitetura vernacular ${ }^{3}$, respeitando-se os critérios normativos ambientais existentes no Brasil. Essas técnicas observam a origem dos materiais, aproveitando-se especialmente os materiais locais. Assim, destacam-se a autenticidade, a simplicidade e a rusticidade dos elementos arquitetônicos e decorativos, primando pelo conforto e qualidade.

Deve-se buscar a ambientação dos equipamentos e o uso de materiais, artesanato e gastronomia locais, permitindo ampliar as possibilidades de interpretação de caracte- 
rísticas importantes do meio ambiente e da cultura em que o ecoturista está inserido. Além de estimular, fortalecer e resgatar o uso de técnicas tradicionais na confecção de produtos, que geram emprego e renda para as populações locais.

\section{Educação Ambiental}

Os trabalhos propostos devem permear os objetivos elencados no Programa Nacional de Educação Ambiental (ProNEA) que visa a integração equilibrada das múltiplas dimensões da sustentabilidade - ambiental, social, cultural, econômicofinanceira, político-institucional, jurídica e mercadológica.

Orienta-se que as atividades do objeto desse Termo de Referência perpassem pela comunicação dos atores envolvidos com o planejamento e execução de ações de educação ambiental em Unidades de Conservação e seu entorno.

Cabe observar que é fundamental inserir no contexto dos roteiros as experiências de formação de monitores locais e a capacitação de agentes multiplicadores capazes de contribuir ao estimular a reflexão e apontar soluções para problemas enfrentados por comunidades tradicionais, promovendo uma efetiva participação social e considerando valores e comportamentos particulares de diversas culturas que compõem nossa sociedade em processos decisórios relacionados ao turismo e à melhoria da qualidade de vida em áreas verdes protegidas.

\section{Interpretação Ambiental}

Todas as atividades de roteirização devem priorizar a interpretação ambiental como a arte de explicar o significado de determinado recurso ou atrativo turístico. Trata-se de proporcionar o entendimento do ambiente natural, despertar a atenção e o interesse do visitante em relação à natureza e à cultura, esclarecendo dados, fatos e correlações que normalmente não são claros ao simples olhar. As características do local são ressaltadas e explicadas em um processo de facilitação da informação, levando o turista a compreender e vivenciar experiências mais significativas, ricas e aprazíveis.

Além disso, a interpretação nos roteiros serve ao propósito de sensibilizar e conscientizar em relação às questões ambientais, fato que a torna uma estratégia de educação ambiental e uma forma adequada de comunicação do conhecimento da natureza e da cultura. É também uma maneira de contribuir para a sustentabilidade, na medida em que as mensagens transmitidas podem mudar ou fortalecer a percepção do turista, estimulando a atenção para as questões ambientais e promovendo a valorização e proteção da natureza - justamente por isso torna-se imperiosa na prática do Ecoturismo.

Os roteiros interpretativos constituem-se em um processo e como tal requer planejamento, denominado Plano de Interpretação, para contemplar etapas importantes: análise do recurso e de suas potencialidades; identificação dos destinatários ou público-alvo da interpretação; formulação dos objetivos da interpretação; 
determinação das mensagens a transmitir; seleção dos meios de interpretação; recomendações para executar tarefas e levantamento das necessidades de pessoal; eleição dos critérios para efetuar a execução e avaliação.

Como método de trabalho para a roteirização é imprescindível inserir a interpretação como ferramenta que promova também a inter-relação entre condutores ambientais locais e ecoturista. As técnicas utilizadas variam de acordo o objetivo da interpretação e do público - que está conhecendo a localidade ou região, visto que não se pode desassociar a área natural interpretada de sua dinâmica sociocultural. Diante desse contexto, cabe ressaltar alguns princípios para a interpretação ambiental na roteirização do Ecoturismo:

- Estimular as percepções e sentidos do visitante, de modo a estabelecer uma compreensão das características singulares do ecossistema vivenciado, para que se sensibilize sobre a importância da conservação;

- Não apenas instruir, mas provocar, estimular a curiosidade do visitante encorajando a explorar o ambiente interpretado por meio do uso dos sentidos - tato, olfato, audição;

- Buscar a interface nos dados técnicos da fauna e flora local com causos, lendas e histórias de ocupação territorial, entre outros;

- Realizar a interpretação em parceria com integrantes da comunidade receptora, estimulando a troca de conhecimentos dos saberes e dos fazeres;

- Utilizar uma linguagem acessível quando o grupo for mais heterogêneo viabilizando a interpretação de aspetos socioambientais complexos para um público mais leigo;

- $\quad$ Preparar-se tecnicamente para atender públicos e produtos de Ecoturismo mais específicos, como observação de aves, orquídeas, mamíferos, entre outros;

- $\quad$ Preparar-se tecnicamente, verificar a acessibilidade dos atrativos e equipamentos turísticos para atender públicos que demandam maior atenção na execução de atividades como pessoas com deficiências ou com mobilidade reduzida;

- Não tentar vender uma verdade universal, mas destacar a diversidade ambiental e suas relações socioculturais com o entorno.

\section{Procedimentos Metodológicos}

Todas as etapas propostas deverão se desenvolver de modo integrado e participativo, acompanhados "pari passu" pela equipe da Coordenadoria de Biodiversidade (COBIO), apoiados pela Coordenadoria de Educação Ambiental e Articulação Social (COEAS), ambas do CONPAM e, pactuados pelos fóruns regionais de 
turismo e cultura.

A fase de informação analítica e avaliativa deve ser procedida de duas formas, a análise dos documentos básicos e projetos existentes ou outros documentos e a realização de pesquisas e levantamentos de campo.

É fundamental que sejam consultados os Planos de Desenvolvimentos Regionais e Inter-regionais, os Planos Estratégicos para o Turismo, o Manual de Informações Turísticas, os módulos de Conjuntura Econômica da Secretaria de Turismo do Ceará (SETUR), os projetos em desenvolvimento e os que estiverem programados. Os dados obtidos deverão ser analisados, avaliados e apresentados de forma textual, em gráficos, tabelas e mapas representativos dos aspectos geográficos, de infraestrutura, atrativos, acessos e outras informações passíveis de mapear.

$\mathrm{Na}$ fase propositiva, após análise dos planos existentes e depois do resultado das pesquisas, serão realizadas as oficinas com a participação dos técnicos do CONPAM, membros dos Fóruns Regionais de Turismo e Cultura e da comunidade do entorno. Como resultados dessas oficinas surgirão os Planos Estratégicos de Desenvolvimento e Ação do Ecoturismo. Na fase de implementação dos roteiros, a avaliação deverá ser feita através de visitas técnicas e outras formas de análise "in loco".

\section{Produtos}

O projeto de implementação para os Roteiros de Ecoturismo nas Unidades de Conservação do Ceará deverá ser apresentado em quatro produtos nos quais deverão ser consideradas e seguidas as recomendações contidas nesta presente proposta.

Produto 1: Relatório dos levantamentos e pesquisas realizados, com o prognóstico dos possíveis Termos de Referências e Projetos Executivos.

Produto 2: Análise situacional e avaliação dos cenários possíveis das regiões e projeção de roteiros.

Produto 3: Planos Estratégicos e de Ação para as 06 (seis) Unidades contempladas para os Parques da Copa.

Produto 4: Documentos-síntese para uma Política Estratégica de Desenvolvimento de Ecoturismo em Unidades de Conservação que contemple as 23 (vinte e três) Unidades de Conservação e Implementação dos Roteiros de Ecoturismo das 06 (seis) Unidades de Conservação selecionadas para os Parques da Copa.

\section{Considerações finais}

Constata-se, parcialmente, que ao longo das pesquisas e da elaboração dessa proposta foi possível visualizar as oportunidades e desafios para a viabilização 
dos roteiros de ecoturismo nas Unidades de Conservação estaduais do Ceará.

Por ora, nota-se que as articulações necessárias para atingir os objetivos desta proposta foram já foram devidamente iniciadas com a institucionalização e instrumentalização legal para encaminhamento dos processos administrativos.

Do ponto de vista técnico, o objeto deste trabalho preconiza, sobretudo a preservação ambiental dos ecossistemas protegidos do Estado do Ceará.

Portanto, com a premência da realização grandes eventos, como a Copa do Mundo, e com a preocupação das questões ambientais que abarcam toda a sociedade, o Governo do Estado do Ceará com as suas políticas públicas está se preparando para receber os turistas com uma gama de serviços e infraestrutura ecologicamente adequada em nível de qualidade e diversidade de produtos turísticos sustentáveis.

\section{Referências bibliográficas}

BRASIL. Diretrizes para uma política nacional de ecoturismo. Brasília: EMBRATUR, 1994.

BRASIL. Ministério do Turismo. Programa de Regionalização do Turismo - Roteiros do Brasil: Turismo e Sustentabilidade. Brasília: MTur, 2007, p. 28.

\section{Notas:}

${ }^{1} \mathrm{~A}$ capacidade de suporte corresponde ao número máximo de visitantes e frequência dos fluxos (dia/mês/ano) que um local pode suportar em relação a possíveis alterações nos meio físico e social.

2Serviços e equipamentos turísticos: conjunto de serviços, edificações e instalações indispensáveis ao desenvolvimento da atividade turística e que existem em função desta. Compreendem os serviços e os equipamentos de hospedagem, alimentação, agenciamento, transporte, eventos, lazer etc. (BRASIL, Ministério do Turismo. Programa de Regionalização do Turismo - Roteiros do Brasil: Introdução à Regionalização do Turismo. Brasília, 2007).

${ }^{3}$ Arquitetura vernácular: entendida como arquitetura comum, anônima, construída sem interferência de arquitetos ou engenheiros - constitui a fisionomia da cidade, ou seja, é aquela que se exprime com linguagens e expressões que refletem o lugar e o ambiente onde foi formada. Uma cidade nunca é igual à outra. As cidades resultam de uma infinidade de diferenças geográficas ou da tradição. BARDA, Marisa. Por que conservar. Revista aU - Arquitetura e Urbanismo. Edição 163 - Outubro 2007. Disponível em http://www.revistaau.com.br. Acesso em Setembro de 2012. 
Hermógenes Henrique Oliveira Nascimento: Conselho de Políticas e Gestão do Meio Ambiente, Fortaleza, CE, Brasil.

Email: henrique.sampa@gmail.com

Link para o currículo Lattes: http://lattes.cnpq.br/0195752487069939

Data de submissão: 28 de julho de 2013

Data de recebimento de correções: 28 de julho de 2013

Data do aceite: 01 de setembro de 2013

Avaliado anonimamente 